\title{
KUI VAJALIK ON GRAMMATIKA?
}

\author{
MARTIN EHALA
}

\section{Sissejuhatus}

$\mathrm{P}$ ierre Bourdieu ([1980] 1991) on tabavalt kirjutanud, kuidas ühiskond loob ja taastoodab legitiimset keelevarianti, mis on tihedalt seotud riigi ja haridussüsteemiga ja mida laias laastus kõik ühiskonnakihid tunnustavad kui keelekasutuse head tava, hoolimata sellest, et vaid valitud kõnelejarühmad omandavad selle loomuliku keeleomandamise käigus, samal ajal kui ühiskonna suurem osa peab kõvasti vaeva nägema, et see koolis ära õppida. Olenemata viisist, kuidas legitiimne keel ehk siis lihtsamalt öeldes normitud kirjakeel omandatakse, moodustab see osa inimese keelelisest kapitalist, mida ta on võimeline ühiskonna toimimisväljadel teist tüüpi kapitalide vastu vahetama, näiteks ligipääsu kaudu tasuvamatele töökohtadele või võimalusega avalikus ühiskondlikus elus kaasa rääkida.

Kuigi Eestis ei ole ehk kirjakeele ja rahvakeele erinevused nii suured, et osa ühiskonnakihtide juurdepääs hüvedele oleks oluliselt raskendatud (välja arvatud nendel, kelle emakeel ei ole eesti keel), on hea kirjakeeleoskus siiski osa ühiskondlikust võimumehhanismist. See ei kehti muidugi ainult kirjakeele kohta. Põhimõtteliselt on iga allkeele oskus keeleline kapital, mis teatud valdkonnas või teatud seltskonnas võimaldab edukalt toimida. Näiteks ei ole tõenäoliselt võimalik teha akadeemilist karjääri, kui inimene ei suuda end väljendada akadeemilise registri nõuete järgi niihästi eesti kui järjest valdavamalt ka inglise keeles. Ei ole võimalik olla jurist, oskamata väljenduda juriidilisele keelele omase keerukuse ja terminoloogiaga. Ei saa olla usutav bürokraat, valdamata nominaalstiili ega valdkonna stampkeelendeid.

Iga erialakeele omandamisse peab inimene investeerima oma aega, et hiljem olla võimeline selles valdkonnas tegutsema. Samas annab selle kapitali valdamine talle võimaluse see enda kasuks tööle panna. Nii peabki tavainimene minema juristi juurde nõu küsima, sest ise ei suuda ta keerulise seaduseteksti nüanssidest läbi närida, bürokraat suudab aga oma žargooniga kehtestada võimu kodaniku üle, kellel on vaja saada mingi kooskõlastus riigiametist. Loomulikult tekitab see ebavõrdsust ja iseäranis keeleteadlased on vaprad võitlema selle eest, et juriidiline keel oleks tavainimesele arusaadavam ja bürokraadid ei kasutaks kohutavat kantseliiti. Kuid ega lingvistid ise sugugi paremad ole.

Nad on haaranud monopoli kirjakeele normide kehtestamise ja kirjeldamise üle ning teevad seda sellises erialases žargoonis, mis tagab, et tavainimene ilma nende abita normide nüanssides orienteeruda ei suuda, mistõttu vajab nõustamist, koolitust ja keeletoimetust, mida suudavad pakkuda üksnes vajaliku erihariduse saanud asjatundjad ehk siis lingvistid ise.

Ma olen kaugel sellest, et seda kõike hukka mõista ja nõuda keelelist võrdsust: ühiskond on hierarhiline ja ma ei usu, et võimu- ja sellega kaasnevaid keelelisi erinevusi oleks võimalik kaotada. Kuid ma nõustun Bourdieuga, et 
ühiskonnas toimub pidev nügimine, millega n-ö tõrjutud rühmad üritavad legitiimse keele piire endale soodsamaks nihutada. Seega ma mõistan niihästi juriste kui ka bürokraate nende soovis muuta oma erialakeel keerukamaks, et säilitada selle üle monopol, samal ajal ma mõistan ka (lingvistide) püüdlust neid seda tegemast takistada. Aga ma leian, et oleks vaja kedagi, kes üritaks ka lingviste ohjeldada nende püüdluses oma valdkonda monopoliseerida. Parema puudumisel üritan seda siin ise teha, mõistes küll hästi võimalikku pahameelt, mida see kolleegide südames võib tekitada.

\section{Kirjakeele monopol}

Kõige tüüpilisemal juhul on kirjakeele monopol valitseva klassi käes (nagu näiteks Prantsusmaal või vanal heal Inglismaal), kelle keelepruugi lingvistid formaliseerivad standardkeele kujul. Seda tehes on keeleteadlased oma olemuselt nagu keelelised pankurid, kes teistele kuuluvalt kapitalilt oma protsendi võtavad. See toimub põhiliselt kahel viisil: esiteks on lingvistidel võimalus teha valik erinevate paralleelvormide vahel, s.t kuulutada osa neist normipärasteks ja osa normivastasteks. Et igas keeles, ka valitsevate klasside keeles, on loomulikku varieeruvust, siis on võimalik alati seda normeerimisega korraldada. Mida täpsemalt paralleelvariantide kasutus reguleeritakse ja mida täpsemalt paronüümsete keelendite tähenduserinevused fikseeritakse, seda kõrgemat protsenti lingvistid nende hoolde usaldatud keeleliselt kapitalilt teenivad, sest mida keerukamad reeglid, seda hädavajalikum on lingvistide abi nendega toimetulekul.

Teiseks kasutavad lingvistid standardkeele reeglite kirjapanemiseks oma erialažargooni, mille olulisemaks tunnuseks on rohke grammatikaterminite kasutus. Selliselt vormistatud reeglite mõistmine eeldab head ülevaadet keele ehitusest ja võimet keelestruktuure analüüsida. Iseenesestmõistetavalt ei suuda tavaline keelekasutaja seda ilma erialase koolituseta teha, mistõttu „keelepankurid” (lingvistid, leksikoloogid, keelekorraldajad, keeletoimetajad ja emakeeleõpetajad) on endale taganud tagasihoidliku, kuid püsiva sissetuleku neile usaldatud kapitali haldamiselt.

Ma ei arva, et see tegevus iseenesest oleks kuidagi taunitav, küsimus on vaid protsendimääras, täpselt nagu ka õigus- või bürokraatiakeele puhul. Küsimus on selles, kuivõrd keeruline on tavainimesele juurdepääs nende valdkondade oskusteabele, seda just eeskätt keelelise väljenduse eripära tõttu. Mida asendamatumaks on erialainimesed muutnud oma vahenduse valdkonna oskusteabele ligipääsemisel, seda taunitavam see tegevus on.

Samal ajal ma ei arva, et erialainimesed kuidagi teadvustatult ja kasuahnelt oma monopoli üritavad kindlustada. Vaevalt et enamik üldse on oma valdkonnale kunagi Bourdieu prisma läbi vaadanud. Ma usun, et erialainimesed lihtsalt püüdlevad järjest täiuslikuma erialase tulemuse poole. Selle tagajärjeks on nähtamatu käe protsess, mis muudab valdkonna väljenduse järjest spetsiifilisemaks ja autsaideritele raskemini ligipääsetavamaks.

Nii võibki keeleteadlane siiralt ja sinisilmselt kinnitada, et „pole võimalik aru saada näiteks kokku- ja lahkukirjutamise reeglitest, kui ei tunta sõnaliike, ega kirjavahemärgireeglitest, kui ei osata määrata lauseliikmeid. Sõnade käänamise ja pööramise süsteemi õppimiseks on tarvis ära tunda välted, 
kindlaks teha, kas ja milline astmevaheldus sõnas esineb” (Sakova 2009), või et „keelereeglid on sõnastatud grammatikaterminites ning baasmõisteid tundmata ei saa (normi)kirjakeelt üldse õppida ega õpetada" (Penjam 2009: 1), või „ma ei kujuta ette, kuidas saab gümnaasiumis õpetada ilma keele struktuuri õpetamata või õppida nii, et oma emakeele ülesehitusest midagi ei tea" (Raun, Filippov 2009). Paraku on neil paljuski õigus, sest süsteem taastoodab iseennast ja katsed asjale valdkonnaväliselt vaadata leiavad tugevat vastuseisu mitte majanduslike huvide võtmes, vaid pigem seetõttu, et muudatused puudutavad erialainimeste väärtussüsteemi, erialast identiteeti ja harjumusi. Samas ei ole ettekujutus, et kirjakeelt pole võimalik ilma grammatikatermineid tundmata sõnastada ega õpetada, mitte vääramatu loodusseadus, vaid lihtsalt väljakujunenud olukorra konstateering. Veidi kriitilisema pilguga analüüsides ilmneb, et suur osa grammatilisest pagasist on kirjakeele omandamiseks ebaoluline, ja ma ei ole esimene, kes seda on märganud.

\section{Veidi ajaloost}

Keskne institutsioon, kus normitud kirjakeele taastootmine aset leiab, on haridussüsteem. Seal toimub tõenäoliselt iga inimese esimene kokkupuude kirjakeele normeerimise diskursusega, s.t mõistesüsteemiga, mille abil kirjakeelt õpetatakse. See on kogu aeg olnud väga grammatikakeskne. Õpikuid kirjutavad keeleteadlased. Emakeeleõpetajad, kes nende järgi õpetavad, on hariduse omandanud ülikoolides nendesamade keeleteadlaste käe all ja sellessamas diskursuses, millega normatiivsed keeleteadlased neid reegleid kõige esmalt on kirjeldanud. Seega pole midagi imestada, et see diskursus on oma olemuselt lingvistiline.

Ka mina usun, et lingvistilisele mõistesüsteemile pole keelekorralduses alternatiivi, sest lingvistika pakub kõige ulatuslikuma ja täpsema mõistelise raamistiku keeleliste nähtuste kirjeldamiseks ja normide fikseerimiseks. Samas ei usu ma nagu mõned mu silmapaistvad eelkäijadki, et kogu see mõistestik oleks vältimatu tavakasutajale või õppurile keelereeglite sõnastamiseks. Seega ei puuduta järgnev kriitika mitte viisi, kuidas kirjakeele norme ja norminguid fikseerida ja defineerida, vaid viisi, kuidas neid norme tavakasutajate jaoks arusaadaval viisil sõnastada ja/või õpetada.

Ilmselt esimesena eesti keele õpetuse ajaloos seadis grammatikapõhiste reeglite otstarbekuse kirjakeele õpetamisel kahtluse alla Nikolai Remmel (vt lähemalt: Maanso 2008b). Tema seisukohad põhinevad väga ulatuslikel kvantitatiivsetel uuringutel, mis ta tegi 1960. aastate koolinoorte seas õigekeelsusreeglite tundmise, õigekeeleoskuse, keelevaistu ja emakeeleõppe hoiakute kohta. Remmel konstateerib, et paljude keelenähtuste, nagu sõnavälte, astmevahelduse, tüüpkondade, käänd- ja kaassõna lahkukirjutuse olemuse mõistmine, käib õpilastele üle jõu, mistõttu ei ole nende grammatilisel kirjeldusel põhinevad reeglid õpilastele arusaadavad ja põhjustavad pigem segadust, kui aitavad vältida vigu. Rohket kinnitust sellele sai Remmel ópilaste tagasisidet uurides, milles paljud kinnitasid, et „keelereegleid ei kasuta kunagi, sest pole neid ilmaski pähe õppinud. Kirjutan ainult vaistu järgi ja toetun põhiliselt näidetele" (Remmel [1971] 2008: 98). Et õpilaste keelevaist üldiselt ei peta, selles veendus Remmel nonsenss-sõnadega tehtud häälikkoostise ja 
vormimoodustuse katsete põhjal, milles õpilased andsid 70-97\% ulatuses kokkulangevaid vastuseid.

Katsete tulemused ajendasid Remmelit loobuma reeglipõhisest emakeeleõpetusest mitmete teemade käsitlemisel ja katsetama selle asemel analoogiapõhist õpetust. Tulemused olid väga muljetavaldavad. Katseklassides saavutasid õpilased 34 protsendipunkti kõrgemaid tulemusi konsonantühendi ja klusiilide õigekirjas ning 24 protsendipunkti kõrgemaid tulemusi kokku- ja lahkukirjutamise õppimisel (Maanso 2008c: 51). Tulemused võinuks olla piisavalt kaalukad, et Remmeli metoodika emakeeleõpetuses üldiseks muuta, kuid paraku nii ei juhtunud. Olen üsna veendunud, et põhjuseks oli emakeeleõpetajate lingvistilis-filloloogiline ettevalmistussüsteem ülikoolides, mida autsaiderist rakenduslingvist mõjutada ei suutnud. Nii valitseb sama filoloogilis-lingvistiline paradigma meie ülikoolides emakeeleõpetajate ettevalmistusel edasi, kuigi riikliku õppekava põhisuunad on oluliselt muutunud ja nõuaks oluliselt teistsugust lähenemist.

Remmelile sekundeeris võib-olla jõulisemaltki Johannes Valgma, kelle kirjutised emakeeleõpetuse muutmisest põhjustasid 1960. aastate keskel ulatusliku diskussiooni (vt lähemalt: Maanso 2008a). Valgma täheldas, et kooli grammatikaõpetuse tulemused on väherõomustavad: tunde pühendatakse sellele palju, kuid tulemused on puudulikud. Isegi emakeeleõpetajaks õppivad üliõpilased ei tea aasta pärast morfoloogia kursust enam muutkondi. Valgma järeldus on karm, aga õiglane: „Morfoloogia ja süntaksi õppimine senisel kujul ei anna kulutatud ajaga võrdelist tulu ja tuleb ratsionaalsemalt ümber korraldada" (Valgma [1965] 2008: 83). Ta esitab ka loendi teemadest, mis õigekirja omandamise eeldusena on vältimatud: „häälikud ja tähed, helilised ja helitud häälikud, sõnaliigid, käänded, tegusõna vormid (eriti käändelised ja pöördelised vormid) [---] lauseõpetusest - mõisted ja lauseanalüüsi oskus, nii et tähtsamaid kongruentsi-, rektsiooni-, sõnade järjekorra ja interpunktsioonireegleid rakendada suudetakse" (Valgma [1965] 2008: 89).

Valgma mõtted olid tollases ajas väga uudsed ja põhjustasid elavat vastukaja. Tema seisukohtadele tuli tegevõpetajatelt üsna palju toetust, kuid vastuseisu akadeemilistest ringkondadest. Põhilise oponendina astus üles Gerda Laugaste Tartu Riiklikust Ülikoolist, kelle seisukoha võib kokku võtta lausega „keele struktuuri tundmata ei saa... ükski kõneleja vajalikku kindlust kätte" (Maanso 2008d: 94).

Paraku ei ole hoiakud ja suhtumised viimase 40 aastaga väga palju muutunud. Kui emakeeleõpetuse metoodikud üldiselt pooldavad pigem Valgma ja Remmeli lähenemist („Kui pöörata nooremates klassides grammatika õpetamisele liiga suurt tähelepanu, siis võib see laste kirjutamise arengut koguni pärssida”; Uusen, Hiiepuu 2011), siis need inimesed (niihästi ühiskonnas kui ka ülikoolis), kes emakeele õpetamise küsimustega otseselt kokku ei puutu, kalduvad pigem toetama müüti, et grammatilise struktuuri tundmine on õigekirja ja eneseväljenduse omandamiseks vältimatu. Püüan järgnevalt analüüsida, kui palju grammatika mõistestikku õigekirjareeglite sõnastamiseks ja omandamiseks tegelikult vaja on. 


\section{Häälikuortograafia}

Vaieldamatult on häälikuortograafia reeglite sõnastamisel vaja kasutada vokaali, konsonandi ja klusiili mõisteid ning helitute ja heliliste häälikute mõisteid. Vältimatu on ka lühikese ja pika hääliku eristamine, kuid kolm häälikupikkust on juba kindlasti saatanast või vähemalt saientoloogiast, sest eesti keele kolm häälikupikkust, mis nii kenasti näivad avalduvat kolmikutes koli : kooli : kooli ja koli : kolli : kolli, on samaväärne teaduslik nonsenss, nagu loodusteadustes oleks väide, et Päike tiirleb ümber Maa (vt lähemalt: Viitso 1979; Hint 1998; Eek 1986; Ehala 1999).

Küsimus ei ole lihtsalt teoreetiline või terminoloogiline. Praeguse kirjutama õpetamise metoodika kohaselt on lühikese, pika ja ülipika hääliku eristamine häälikupikkuste märkimise vältimatu eeldus. Selline arusaam muudab häälikuõigekirja õppimise tarbetult keeruliseks ja aeganõudvaks, sest üldiselt eesti õigekiri kolme häälikupikkust kirjas ei märgi. Vaja läheb seda vaid sulghäälikute pikkuse märkimisel ja sedagi mitte igal pool, vaid ühes üsna täpselt piiritletud ümbruses: lühikese täishääliku järel. Seega on ühest eesti keele õigekirja erijuhtumist tehtud üldine printsiip, hoolimata sellest, et ülejäänud häälikute õigekiri seda arvesse ei võta. See on lihtsalt aja raiskamine, häälikute õigekirja õppimist tuleks alustada hoopis teisest otsast ja ilma kolme väldet mainimata.

Selle metoodika kohaselt on õigekirjaõpetuses oluline eristada lühikest häälikut (I välde) pikast häälikust (II või III välde), kuid pikkade häälikute omavahelised iseärasused võib jätta käsitlemata, sest õigekiri neid ei kajasta. Niisiis piisaks õigekirja õpetamiseks kolmest põhireeglist:

- Lühike häälik märgitakse ühe tähega, pikk häälik kahe tähega, näiteks kala, kaalu, pala, palli.

- Häälikuühendis kirjutatakse iga häälik ühe tähega (häälikuühendi moodustavad ühes sõnas kõrvuti asetsevad erinevad täishäälikud või kaashäälikud). Nii näiteks on pikk sõnas ulguma l-häälik, sõnas märg $r$-häälik, sõnas aur $u$-häälik, aga häälikuühendi kirjutamise reegli järgi kirjutatakse need kõik alati ühe tähega.

- Sulghäälikud moodustavad erandi: lühike sulghäälik kirjutatakse $g, b$, $d$-ga, pikk sulghäälik ühe $k, p, t$-ga ja ainult erandjuhtumil kirjutatakse pikk sulghäälik kahe tähega (vt joonist 1).

Pika sulghääliku õigesti kirjutamiseks peab teadma, et kahe tähega saab seda kirjutada ainult lühikese täishääliku järel (see nukk, seda nukku). Igal pool mujal märgitakse pikk sulghäälik ühe $k, p$ või $t$-ga.

Keeruliseks teeb asja see, et lühikese täishääliku järel võib pikka sulghäälikut ka ühe tähega kirjutada (selle nuku, see taburet, ei kirjuta). Ja alles siin läheb eesti keele häälikuortograafias tõesti vaja eristada II ja III väldet. See on oluline erinevus praeguse metoodikaga võrreldes. Kui praegu kulutatakse õpetamisel palju aega II ja III välte erisuse tajuma õppimisele selliste häälikute puhul, mille kirjutamisel sellel erinevusel mingit rolli ei ole, siis uue metoodika juures oleks see vaatluse all vaid seal, kus see tõesti on oluline. Õnneks on nukku: nuku häälikuümbrus selline, kus II ja III välte erinevus tõesti selgelt eristub. Enamasti põhjendatakse vältedrilli ka sellega, et seda läheb ju hiljem vormiõpetuse õppimisel vaja. 


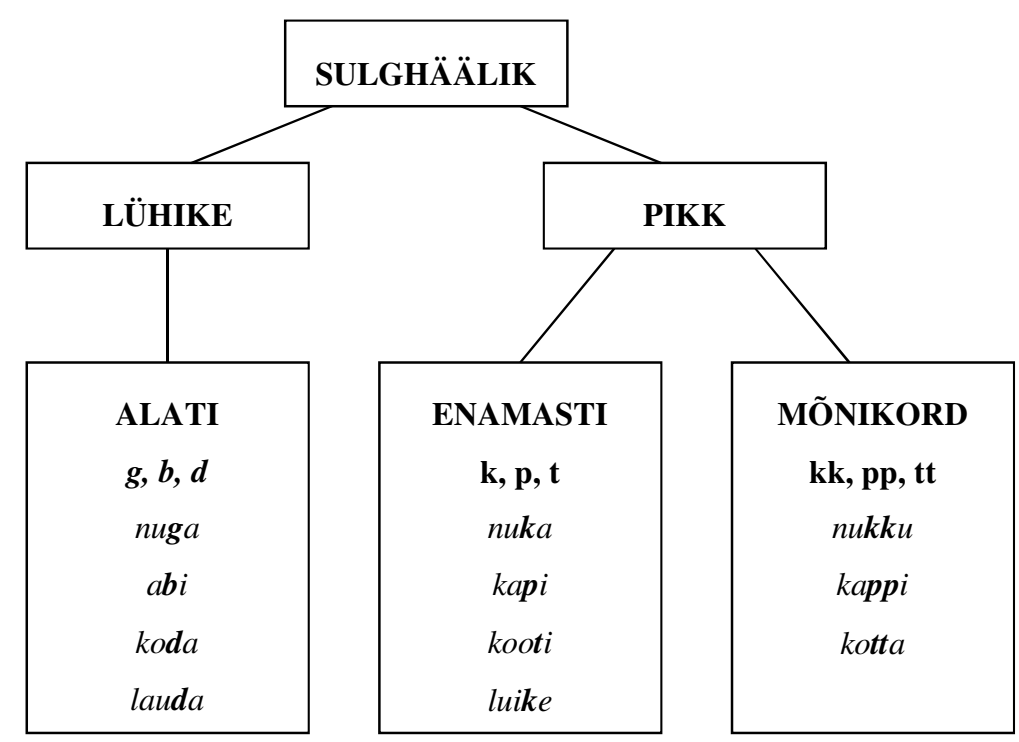

J o o n i s 1. Sulghääliku pikkuse märkimine kirjas.

\section{Vormiópetus}

Vormiõpetuse valdkonnas on õigekeelsusega seotud kaks teemat: õigete tüvevariantide valik (näiteks töötatakse, mitte töödatakse) ja õigete vormide moodustamine (näiteks kasse, mitte kassisi). Mõlemad teemad puudutavad otseselt keeleoskust ja alles kaudselt õigekirjaoskust, sest vead kirjas tulenevad siin vigasest keeletunnetusest, mitte oskamatusest kirjutada. Seega, õpetades õigeid vorme moodustama, kaob enamik selliseid vigu ka sõnade kirjapildis.

Traditsiooniliselt üritatakse seda ravida ohtra vormiõpetusega. Selline tegevus sarnaneb kahurist kärbse laskmisega, sest eesti morfoloogia on keeruline, kuid selle tundmine aitab vaid minimaalselt kaasa õigete vormide moodustamisele. Põhjus on selles, et eesti keele sõnade vormimoodustus sõltub sõna tüve omadustest ja enamik vigu tulenevad sellest, et ei tunta õigeid tüvevariante. Näiteks levinud väärvormi *kontserdite moodustamine tuleneb sellest, et ei tunta sõna õiget osastava tüve kontserti. Selle asemel lähtutakse mitmuse osastava moodustamisel väärvormist *kontserdit. Samalaadseid veanäiteid võiks tuua veel rohkesti.

Tõsi, eesti sõnad liigituvad tüüpkondadesse silpide arvu, astmevahelduse ja väldete alusel, aga nende määramine kriitilises sõnas ei aita õpilast sammugi edasi, sest lingvistilise analüüsi aluseks on ju tema enda keeleteadmine. Kui tema keelekasutuses ei ole sõna astmevahelduslik (ohtlik: ohtliku: ohtlikut), siis pole silpide, välte ega astmevahelduse määramisest samuti kasu. Ta lihtsalt kinnistab oma analüüsiga omaenda väärkasutuse.

Seega eesti keele õiget vormimoodustust ei ole võimalik turgutada välteid ja astmevaheldust õpetades. Kriitilisi sõnu tuleb õpetada koos nende vormidega täpselt samamoodi, nagu saksa keeles tuleb iga nimisõna puhul lisaks tähendusele teada selle sugu: kas ta on der, die või das. Seega ohtlik-tüübi 
õpetamisel tuleks öelda, et selle liitega sõnad käänduvad nagu tikk: tiku: tik$k u$. Nii on õige vormimoodustus hoopis eduka sõnavaraarenduse loomulik kaasnähe, mitte morfoloogiaõpetuse tulemus.

On veel üks põhjus, miks põhjalik väldete, astmevahelduse ja tüüpkondade õpetus ei ole õige vormimoodustuse jaoks oluline: suurema osa õpilaste jaoks ei ole enamiku sõnade muutmine vähimalgi määral problemaatiline seda kinnitasid veenvalt juba Remmeli katsed. Tema katseid kordas 40 aastat hiljem Tiina Tärk (2008), kelle tulemustes ilmnes sama tendents, kuigi vastuste hajuvus oli mõnevõrra suurem: keskmiselt oli domineeriva vormi osakaal vastustes 10 protsendipunkti madalam kui Remmeli tulemustes. Nagu Tärk märgib, võib põhjuseks olla asjaolu, et tänapäeva eesti koolis on umbes $10 \%$ õpilasi, kelle emakeel ei ole eesti keel, samuti võib olla teiste keelte ja liberaalsema keelekorralduse mõjul teisenenud ka emakeelekõnelejate keeletunnetus. Nii või teisiti, formaalne grammatikadrill ei aita vähimalgi määral vältida inimesele omaseid vormimoodustusvigu, tulgu need siis ta kodusest keelest, murdetaustast või keele muutumisest.

Erandiks on lühikese mitmuse osastava (põlle $\rightarrow$ põlli) ning kesk- ja ülivõrde (musta $\rightarrow$ mustem $\rightarrow$ mustim) moodustamine. Nende vormide moodustamisel eksitakse palju, sest välja arvatud lihtsamatel juhtudel ( $i$-tüvelised sõnad nagu kommunisti $\rightarrow$ kommuniste), on vokaalivahelduse reeglid suhteliselt keerukad. Samas ei vaja selle vormimoodustuse osa õppimine mingeid grammatilisi eriteadmisi: vokaalide teisenduse reeglid tuleb lihtsalt pähe õppida ja ega siin paremat abimeest pole kui kass kõrtsis ei käi ja eks ämm söö kodus sütt, kuivõrd poliitiliselt ebakorrektne viimane neist tänapäeval ka ei tundu.

Karm kokkuvõte õige vormimoodustuse õpetamisest on see, et tuleks loobuda niihästi väldete kui ka astmevahelduse õpetamisest kui täiesti ebaproduktiivsest viisist õiget vormimoodustust turgutada ja keskenduda selle asemel sõnavaraarendusele, mille üheks oluliseks eesmärgiks peaks olema kujundada harjumus kasutada elektroonilist „Eesti keele seletavat sõnaraamatut”. Sest ainus viis kahtluse korral õige vormi leidmiseks on kasutada sõnaraamatut.

\section{Lauseõpetus}

Süntaksi valdkond puudutab päris mitut õigekeelsusteemat, kõigepealt muidugi interpunktsiooni, aga ka ühildumist, rektsiooni, otse- ja kaudkõnet, sõnajärge. Küsimus on selles, kui palju süntaksiteadmisi on vaja ülalmainitud valdkondade õigekeelsusreeglite mõistmiseks ja õppimiseks.

Võtan kõigepealt vaatluse alla kirjavahemärgistuse. Traditsiooniliselt on põhjalikku lauseanalüüsi peetud kirjavahemärgistamise eelduseks. Tõesti, interpunktsioonireeglid on sõnastatud süntaksi mõisteid kasutades ja grammatilistele suhetele viidates. Sellise traditsiooni olemasolu võib täiesti mõista, sest eks ole kirjakeele normide väljatöötamine olnud aegade algusest peale filoloogide ja keeleteadlaste töövaldkond.

Kui vaadata ortograafiat tõesti eelarvamustevaba pilguga, siis ilmneb, et interpunktsioonireeglid (rääkimata muudest õigekeelsusreeglitest) lähtuvad palju enam lause semantilisest liigendusest kui grammatilisest. Seejuures on reeglite aluseks olevad semantilised määratlused palju üldisemad kui gram- 
matilisest struktuurist lähtuvad reeglid. Sellel tähelepanekul on oluline praktiline väärtus: semantikast lähtuvaid reegleid on tavalisel keelekasutajal lihtsam mõista, sest üldjuhul ei ole lause (teksti) semantiliseks analüüsiks vaja kuigi palju erialaterminoloogiat tunda. Seega oleks semantikast lähtuvad ortograafiakäsiraamatud kergemini mõistetavad, samuti võiks eeldada, et semantikast lähtuv ortograafiaõpetus emakeeletundides oleks tõhusam, sest vajab kirjakeele reeglistiku omandamiseks vähem teoreetilisi eelteadmisi kui praegune süsteem.

Tegelikult ma usun, et kirjavahemärgistiku põhimõtted lähtuvadki suuresti semantilistest kriteeriumidest, s.t koma ja muude kirjavahemärkide kasutus peab kergendama lause mõttest aru saamist. Paraku on nad kirja pandud grammatika terminoloogias. Semantiliste põhimõtete ja nende grammatilise kirjapanemise vahel tekib mõnikord vastuolu, mis tekitab erandeid. Iseäranis ilmekas on järgnev näide:

Tema jäi iga ilmaga oma valvepostile, silmitses varemeis küla nagu tunnimees, venitas roostes lõotsa, laulis väsimusest käheda häälega vanu eesti laule, ja kui metskitsed eriti julgeks läksid ja lausa kunagisele külatänavale rohtu ja noori lepavõsusid sööma kõndisid, siis keerutas käristit. Andrus Kivirähk „Romeo ja Julia”

Grammatilisest struktuurist lähtuvalt ei peaks ja ees koma olema, sest see alustab sama tasandi osalauset. Koma peaks olema vahetult ja järel, kui-kõrvallause eraldamiseks. Ometi reegel on vabam ega lähtu mitte niivõrd struktuuripõhimõttest, kuivõrd just avaramast semantilisest lähenemisest, mille kohaselt ja kuulub kokku järgneva lauseosaga.

Või võtame lause mõiste. Seda on vaja kas või selleks, et osata punkti panna. Traditsiooniline lause definitsioon lähtub finiitse verbivormi olemasolust, kuid praktilises kirjavahemärgistuses pole see lausemõiste eriti abistav. Tulemuslikum on lähtuda semantilisest põhimõttest, et lause on teksti osa, mis väljendab üht terviklikku mõtet. Mis on terviklik mõte, sõltub täiel määral sellest, kuidas kirjutaja oma mõttevoogu liigendab, näiteks:

Lühter. Võtan kinni. Tõmban. Põrandal.

Kaur Kender „Iseseisvuspäev”

Ma ihkasin näha ta tuksuvat pinda kui magava hiiglase raudrü̈s rinda ja kuulata laineid, mis veerevad randa kui tuiskavad leegid, mis raksuvad, mis kirglikult kutsudes tuksuvad, mis mürinal maltrannale vaovad ja siis jällegi kaovad kui vägi, mis taganeb vaenlase eest, või põdrakari läeb põleva padriku eest.

Friedebert Tuglas „Meri”

Seega, lause kui terviklik mõte võib olla väga lühike või väga pikk. Et liigitus on semantiline, siis ei ole otstarbekas lause piiride määratlemisel lähtuda finiitse verbivormi olemasolust. Võimalike lausete diapasoon on palju laiem, hõlmates vaeglauseid, prototüüpseid lihtlauseid, koondlauseid, lauselühendiga või kiiluga lauseid, rindlauseid, põimlauseid ja segaliitlauseid, mille osalausete hulgas võib olla vaeglauseid, koondlauseid, kiiluga lauseid ja lau- 
selühendiga lauseid. Ühesõnaga tegelik lausete mitmekesisus on sedavõrd suurem, et finiitsete verbivormide otsimine lauses osalausete eristamiseks lihtsalt ei toimi ja komastamisel tuleb kasutada pigem võimet eristada mõttevoo liigenduses osi, kui üritada teha formaalset süntaktilist analüüsi.

Mõttevoo liigenduse analüüsil tuleks lähtuda põhimõttest, et pikkades lausetes on sageli rohkem kui üks mõte. Iga selline mõte moodustab lausest ühe osalause. Osalaused on ühendatud üheks terviklikuks mõtteks kas sidesõnade, kirjavahemärkide või mõlema abil. Kohase sidendi (ka koma, kooloni, semikooloni, mõttekriipsu) valik sõltub sellest, kui tihedalt on lause kui tervikliku mõtte osad omavahel tähenduslikult seotud.

Kõige tihedamat seost märgivad sidesõnad ja, ning, ega, või. Sidesõnad ja, ning annavad edasi mõtete järgnevust või koosolu, kusjuures ja ühendab tihedamalt kui ning. Koma ja, ning asemel väljendab veidi suuremat eraldatust, koma ja, ning ees veelgi suuremat eraldatust (lause Peeter vaikis, ja linnud lendasid lõunasse ei saa olla vale, kui kirjutaja soovib rõhutada nende kahe sündmuse paralleelsust, teineteisesse mittepuutumist) ning semikoolon mõtete kõige suuremat, peaaegu punktiga võrdset eraldatust.

Rindlause eristamine põimlausest toimub tavakasutajal tõenäoliselt samuti sisuanalüüsi põhjal, määravaks on siin muidugi alistavate sidesõnade tundmine. Lauseliikmete tundmine ei ole selleks vajalik. Tähtis on mõista, et sellised strukturaalselt defineeritud mõisted nagu alistatud kõrvallause, kiillause, lisand, järeltäiend ja üte on mõttevoo liigenduse seisukohalt samalaadsed nähtused: nad täpsustavad või täiendavad peamist mõttevoogu mingi detailiga, mis on seda mõttevoogu lõhkuva iseloomuga, ja et lugejale kergemaks teha arusaamist, millal kõrvalepõige algab ja millal lõpeb, siis eraldatakse täpsustus üldjuhul mõlemalt poolt komaga:

Tabel 1.

\section{Täpsustuste kirjavahemärgistus}

üte

kiil

järeltäiend

järellisand

kõrvallause
Ei, mu härrad, meie asjatust uudishimust tingitud pahed on niisama vanad kui maailm. Meie hulgas, tõsi küll, ei oleks Sokrates joonud surmaputke mürki, aga ta oleks joonud-ja palju kibedamast karikast - solvavat irvitust ja põlgust, mis on sada korda hullem kui surm. Naisüliópilane, töökas ja korralik, üürib ahiküttega toa vaikses linnajaos.

Mis puutub meisse, tavalistesse inimestesse, kellele taevas ei ole jaganud nii suuri vaimuandeid ja kellele ta ei ole määranud osaks saama nii suurt au, siis jäägem oma hämarusse.

Ta lendab kohale, kui tunneb moosisaia lõhna, ning nõelab õelalt sööjat.

Seega tuleks interpunktsioonireeglite esitamisel kõik need nähtused esitada üheskoos ühe reegli rakendumisena erineva mahuga täpsustuste puhul. See võimaldaks ka näidata, kuidas kirjavahemärgi valik sõltub sellest, kui 
sujuvalt või hakkivalt üks või teine täpsustus lause peamise mõttevooga seostub (on ju koma kõrval võimalik kasutada mõttekriipse, sulge või muidki eraldajaid, nagu kaldkiri).

Tähelepanuväärne on see, et samad täpsustused on võimalik esitada lause struktuuriga tihedamalt seotuna nii, et koma vaja ei ole:

Töökas ja korralik naisüliõpilane üürib ahiküttega toa vaikses linnajaos. Meie, tavaliste inimeste hinnangul peaks justiitsminister tagasi astuma. Aga ta oleks joonud palju kibedamast karikast solvavat irvitust ja mürki.

Samal ajal ei ole selle erinevuse mõistmiseks vaja tunda lause struktuuri: loomulik keeletunne ütleb inimesele, millisel puhul on tegu mõttevoo katkestusega, millisel puhul mitte. Seda tunnetust saab minu hinnangul paremini arendada analoogiapõhiste näidete toomisega kui lause struktuuri analüüsil põhinevate reeglite õppimisega.

Semantilist lauseanalüüsi saaks edukalt kasutada ka korduvate lauseliikmete kirjavahemärgistusel. Sest näiteks koondlause kirjavahemärgistuseks ei ole vaja teada korduvate lauseliikmete nime, s.t et korduvad just sihitised, alused või määrused. Koondlause on võimalik tuvastada selle kaudu, et selles on mitu sama ülesannet täitvat lauseliiget, või teiste sõnadega, et selles on mitu samas rollis olevat moodustajat. Näiteks lauses Kass murdis hiire, roti ja merisea on hiir, rott ja merisiga lauses täpselt samas rollis. Selleks et korduvaid lauseliikmeid korralikult komastada, on vaja võimet ära tunda loetelu ja eristada seda teineteist hõlmavate või eriliigiliste elementide järgnevusest. See on puhas semantiline analüüs, mida pole üldse vaja keerulisemaks muuta lauseliikme mõiste kasutamisega.

Lauselühendi kirjavahemärgistuseks on vaja ära tunda verbi käändelisi vorme ja suuta määrata, kas nad on lauselühendi alguses või lõpus. Käändelised vormid on hästi eristatavad ja nende tuvastamisest piisab komakasutuseks täiesti, mingit süntaktilist analüüsi pole selleks vaja, veelgi vähem oluline on see, millise lauseliikme rollis lauselühend on. Kokkuvõtteks võib öelda, et süntaktiline analüüs on interpunktsiooni õppimiseks suuresti ebavajalik ning liiga keerukas, mistõttu vähegi raskemate lausetega satub tavakasutaja otsekohe hätta, kulutab lahenduse leidmiseks ebaproportsionaalselt palju aega ja kogeb frustratsiooni. Seetõttu tuleks kasutada interpunktsiooni aluseks olevaid üldisemaid semantilisi põhimõtteid ja illustreerida neid näitelausetega, s.t kasutada analoogiapõhist mõistmist.

Ülejäänud õigekirja seosed süntaktiliste teadmistega on veelgi kaudsemad. Ühildumine ja rektsioon on valdkonnad, kus maailma keeltes on suhteliselt suur varieerumine. Näiteks eesti keeles minnakse tööle (alaleütlev) ja aidatakse ema (osastav), soome keeles aga minnakse töösse (mennään työhön) ja vene keeles aidatakse emale (помочь маме). Eesti keeles on kaks raamatut ainsuses, inglise keeles mitmuses (two books). Isegi ühe keele sees on olukord erinev. Näiteks sõidetakse mõnikord Loksale (alaleütlev) ja mõnikord Tartusse (sisseütlev). Ühegi sellise reegli jaoks ei ole võimalik anda ratsionaalset seletust, need on iseärasused, mis tuleb lihtsalt ära õppida. Selleks ei ole vaja mingeid süntaktilisi eelteadmisi, rääkimata keeruliste ühildumise ja rektsiooni terminite tundmisest: õigeid keelendeid on lihtsam õppida näidete ja analoogia põhjal. Sel, millise tarindiga on tegu või milline on ta sisestruktuur, 
pole vähimatki tähtsust. Seejuures tuleks õpetamisel keskenduda vaid neile tarinditele, milles tõesti eksitakse. Kogu selline teave võiks olla rubriigis „Käänete õige tarvitamine”.

Ka otse- ja kaudkõne vastavuse määratlemiseks ja teatamislaadide vastastikuse „tõlkimise” tundmiseks ei ole vaja lauseliikmeid tunda, küll aga teada asesõna mõistet ja osata asesõnu asjakohaselt muuta. Näiteks Poliitikud ütlesid: „Me ei taha teile rohkem pettumusi valmistada.” $\rightarrow$ Poliitikud ütlesid, et nad ei taha meile rohkem pettumusi valmistada. Tõenäoliselt on selle valdkonna omandamiseks efektiivseim viis kasutada analoogiat ja selle eeskujul harjutada, kuni intuitiivsed reeglid on kinnistunud.

Sõnajärg on eesti keeles paindlik, põhilised reeglid puudutavad tegusõna asukohta. Sõnajärje omandamiseks on kindlasti vaja tunda lausetuuma ehk öeldise mõistet, teisi lauseliikmeid ei ole vaja nimeliselt tunda. Piisab teadmisest, et lausetuum on tavaliselt lauses teises positsioonis ja talle eelneb mingi lauseliige. Ja siingi piisab lausetuuma mõistmiseks, kui teatakse, et see on tegevust väljendav sõna, nagu lauses Hommikul paistab päike või Peeter hakkas romaani kirjutama. Ühesõnaga, analoogia on ka siin tõenäoliselt efektiivseim viis reegli esitamiseks.

Niisiis tundub, et interpunktsiooni õpetamisel on süntaktilise analüüsi osatähtsus tugevasti üle hinnatud. Enamiku interpunktsioonireeglite mõistmiseks on vaja tunda sõnatasandi nähtusi (sidesõnade liike ja tegusõna käändelisi vorme) ja üldisi semantilisi põhimõtteid, mille põhjal mõttevoog lauses liigendub. Kindlasti on ka mõningane süntaksimõistete tundmine kasulik, aga arvatavasti kahaneb süntaksiõpetuse kasutegur interpunktsioonioskuste parandamise vahendina iga sellele pühendatud tunniga. Võtmeküsimus ongi, mis hetkest alates on tegemist juba puhta ajaraiskamisega. See on täiesti arvestatav rakenduslingvistiline uurimisteema, mille väljundiks oleks optimaalse keerukusega sõnastatud kirjavahemärgistuse käsiraamat koos juurdekuuluva õpetamise metoodikaga.

\section{Muud õigekirjavaldkonnad}

Ülejäänud olulistest õigekirjavaldkondadest tõuseb kindlasti esile kokku- ja lahkukirjutus, mille omandamiseks on vaja tunda sõnaliike. Suur osa liigituse alusest on semantiline (nimisõnad, omadussõnad, tegusõnad, arvsõnad), kuid määrsõnade ja kaassõnade puhul sellest ei piisa ja arvestada tuleks ka nende süntaktilist käitumist. Selline analüüs on tavakasutajale ilmselgelt liiga keeruline, seda enam, et nende sõnaliikide piirid ei ole siin kuigi selged ja samad sõnad võivad olla kord määrsõnad, kord kaassõnad, lisaks meenutavad nad sageli mõnd nimisõna vormi. Nende nüansside omandamiseks läheks vaja palju aega, mille kasutegur on ilmselt õigekirja seisukohalt üsna väike, sest muutumatute sõnade kokku- ja lahkukirjutuse reeglid on nii paljude erandite ja alatüüpidega, et selles orienteerumine lingvistiliste terminite abil pole lihtsalt otstarbekas - lihtsam on opereerida üksikjuhtudega.

Seetõttu on näiteks Sõnaris selle valdkonna reeglite sõnastamisel lähtutud välistamisreeglitest. See on reeglitüüp, mis eristab lihtsalt määratletavad tüübid positiivse tuvastuse kaudu, ja kõik keerukamad tüübid võtab kokku kategooriasse midagi muud. Selle kategooria liigendamisel kordub taas sama 
mudel, mis toob esile olulisemad kategooriad ja jätab jäägi omakorda kategooriasse midagi muud. Ortogrammide sagedust arvestades saab koostada reeglisüsteemi, mis annab produktiivse tüübi või väga sagedase erandsõna reeglid paari otsustuse põhjal, keerukamate ja harvemate määratlemiseks tuleb teha rohkem analüüsi ning väga harva esinevate juhtude lahendamiseks tuleb kõige rohkem vaeva näha

Joonisel 2 on kujutatud Sõnari kokku- ja lahkukirjutusreeglite leidmise algoritmi kolme etappi, mis näitavad, kuidas leida muutumatute sõnade reegleid. Muutumatute sõnade klassi positiivsest defineerimisest on loobutud selle sõnaklassi ebamäärasuse tõttu. Seega, muutumatud sõnad on kõik need, mis jäävad üle arvsõnadest, omadussõnadest, tegusõnadest ja nimisõnadest. Sellest hulgast tuuakse analüüsi järgmisel etapil eraldi välja kõige sagedase$\mathrm{mad} \mathrm{ja} / \mathrm{või}$ segasemad (s.t üldreeglile mitte alluvad) juhtumid (pool, kombel, jõul jt) koos näidetega mõlema kasutusjuhtumi kohta (näiteks sealpool ja

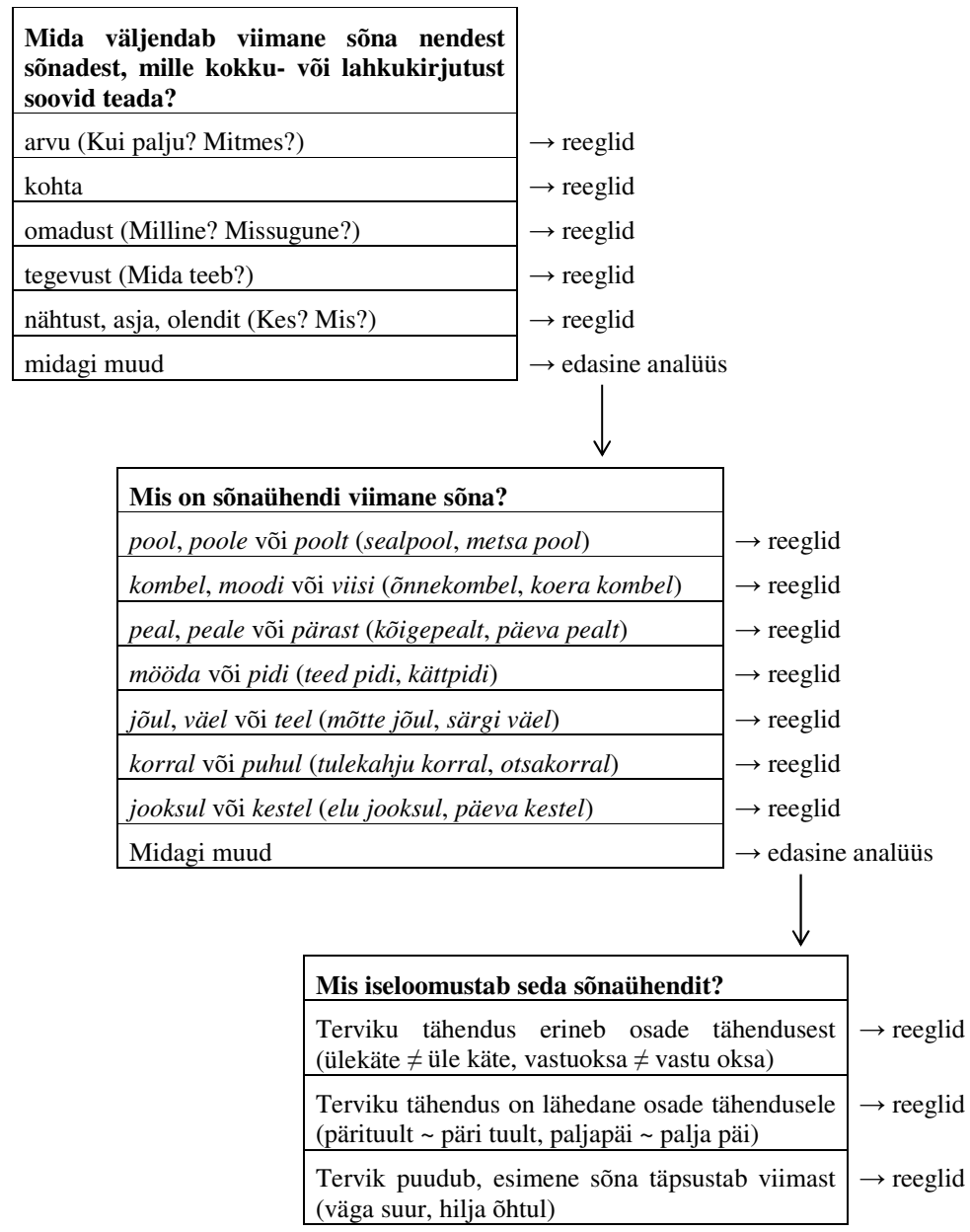

J o o n i s 2. Muutumatute sõnade kokku- ja lahkukirjutusreeglite otsimise algoritm. 
metsa pool). Põhimõtteliselt võib hea keeletunnetusega inimene juba nende näidete põhjal leida oma juhtumile lahenduse ega pea enam järgmisele lehele täpsemate reeglite lugemiseks minema. Kui ta analüüsi sellel etapil ei leia oma juhtumile kategooriat, valib ta taas võimaluse midagi muud. See viib analüüsi viimasesse etappi, kus on esitatud kõige üldisemad muutumatute sõnade kokku- ja lahkukirjutusreeglid. Üldised reeglid on jäetud analüüsi lõppu välistamaks võimalust, et kasutaja üldreeglist lähtuvalt eksiks mõne erandi puhul. Seetõttu on üksikjuhud esitatud enne üldreeglit.

Ülejäänud õigekirjavaldkondades orienteerumine (algustähereeglid, lühendamine, numbrite ja nimede kirjutamine) eeldab veelgi vähem lingvistilisi taustateadmisi ja nii on näiteks Sõnaris kõik need valdkonnad sõnastatud puhtalt tähenduspõhiseid mõisteid kasutades samasuguste otsustuspuude abil nagu joonisel 2. Küllap võib Sõnaris olla ka ebatäpsusi või vigu algoritmide koostamisel, kuid et tegu on kogu õigekirjavaldkonda katva käsiraamatuga, siis ei ole vaidluse all küsimus, k a s õigekirjareegleid saab esitada üldisi semantilisi printsiipe kasutades, vaid see, $\mathrm{k}$ u i d a s seda parimal võimalikul viisil teha.

\section{Kokkuvõte}

Ilmselt tähendab semantilise ortograafia väljaarendamine seda, et kaob ära ainuke rakenduslik vajadus grammatikaõpetuse jaoks emakeeleõpetuses. See võib tunduda paljudele haritlastele järjekordse kultuuri allakäigu märgina, kuid vaadakem karmile reaalsusele näkku. Grammatikale tehakse üldhariduskoolis n-ö kolm ja pool ringi peale: algkoolis õpetatakse häälikusüsteemi täheortograafia õppimiseks, teises kooliastmes õpitakse kõiki keelesüsteemi osi koos põhimõistetega lihtsal tasemel, kolmandal kooliastmel juba süvendatult ning gümnaasiumis veel ühe korra. Samal ajal ei jää sellest õppimisest suurt midagi külge ja „Eesti keele käsiraamatu” stiilis õigekirjareeglid on raskusteta mõistetavad vaid filoloogide kitsale ringile. Ülejäänud saavad sealt vaid tunde, et nad midagi ei oska, ja peavad oma keelekasutust häbenema. Seda olukorda tuleks muuta ja luua õigekirja käsiraamatud ja õpetamise metoodika, mis hõlbustaks tavakasutaja ligipääsu legitiimsele keelele. Täpselt nii, nagu me soovime, et õiguskeel või asjaajamiskeel oleks tavakasutajale mõistetav.

Siinne artikkel on valminud sihtfinantseeritava teema SF0180084s08 „Eesti keele morfosüntaktiline ehitus ja areng” raames.

\section{Kirjandus}

B o u r die u, Pierre [1980] 1991. The production and reproduction of legitimate language. - Language and Symbolic Power. Toim John B Thompson. Cambridge, Massachusetts: Harvard University Press, lk 43-65.

E e k, Arvo 1986. Problems of Estonian word prosody. - Estonian Papers in Phonetics 1984-1985. Tallinn, lk 13-66. 
E h a l a, Martin 1999. Eesti väldete probleemi üks lahendusi. - Keel ja Kirjandus, nr 6, lk 378-386; nr 7, lk 453-466.

H i n t, Mati 1998. Häälikutest sõnadeni. Eesti keele häälikusüsteem üldkeeleteaduslikul taustal. 2., ümbertöötatud tr. Tallinn: Eesti Keele Sihtasutus.

M a a n s o, Viivi (toim) 2008a. Keele- ja koolimees Johannes Valgma. Artikleid ja bibliograafia. (Eesti keele ruum. EÕIK, Emakeeleõpetuse Infokeskuse toimetised 2.) Tallinn: TLÜ Kirjastus.

M a a n s o, Viivi (koost) 2008b. Nikolai Remmel eesti keelele ja koolile. Artikleid ja bibliograafia. (Eesti keele ruum. EÕIK, Emakeeleõpetuse Infokeskuse toimetised 3.) Tallinn: TLÜ Kirjastus.

M a a n s o, Viivi (koost) 2008c. Nikolai Remmelilt emakeele õpetamiseks. - Nikolai Remmel eesti keelele ja koolile. Artikleid ja bibliograafia. (Eesti keele ruum. EÕIK, Emakeeleõpetuse Infokeskuse toimetised 3.) Tallinn: TLÜ Kirjastus, lk $43-58$.

M a a n s o, Viivi (toim) 2008d. Vastukaja J. Valgma 1965.-1966. aasta poleemilistele kirjutistele. - Keele- ja koolimees Johannes Valgma. Artikleid ja bibliograafia. (Eesti keele ruum. EÕIK, Emakeeleõpetuse Infokeskuse toimetised 2.) Tallinn: TLÜ Kirjastus, lk 93-97.

P e nj a m, Tiia 2009. Emakeeleoskuse ja -oskamatuse vahel. - Õpetajate Leht 11. IX, lk 1.

P e n j a m, Pille 2009. Headest kavatsustest heade oskusteni on pikk tee. - Õpetajate Leht 21 . VIII, lk 7.

R a u n, Alo, Fili p p ov, Madis 2009. Emakeeleõppe reformikava kärbib teooria tiibu. Postimees 9. XII (vt http://www.postimees.ee/198933/emakeeleoppe-reformikava-karbib-teooria-tiibu).

R e m m e 1, Nikolai [1971] 2008. Eesti keel õpilase pilguga. - Nikolai Remmel eesti keelele ja koolile. Artikleid ja bibliograafia. Koost V. Maanso. (Eesti keele ruum. EÕIK, Emakeeleõpetuse Infokeskuse toimetised 3.) Tallinn: TLÜ Kirjastus, lk 76-139.

S a k ova, Aija 2009. Üliõpilaste keeleoskus rajaneb sageli vaid intuitsioonil. Universitas Tartuensis 2. IV.

Tärk, Tiina 2008. Eesti keel tänase õpilase pilguga: Nikolai Remmeli katse 2008. - Nikolai Remmel eesti keelele ja koolile. Artikleid ja bibliograafia. Koost V. Maanso. (Eesti keele ruum. EÕIK, Emakeeleõpetuse Infokeskuse toimetised 3.) Tallinn: TLÜ Kirjastus. lk 140-151.

U u sen, Anne, Hii e pu u, Ene 2011. Kirjutamine I kooliastmes. Veebiteavik http://www.oppekava.ee/index.php/LINK_24._Kirjutamine (2. VI 2012).

Valg m a, Johannes [1965] 2008. Kas suur tarkus mõneks aastaks või oskused kogu eluks? - Keele- ja koolimees Johannes Valgma. Artikleid ja bibliograafia. Toim V. Maanso. Eesti keele ruum EÕIK toimetised 2. Emakeeleõpetuse Infokeskus: Tallinn, lk 78-83.

V a l g m a, Johannes [1966] 2008. Grammatika või elav keel? - Keele- ja koolimees Johannes Valgma. Artikleid ja bibliograafia. Toim V. Maanso. (Eesti keele ruum. EÕIK, Emakeeleõpetuse Infokeskuse toimetised 2.) Tallinn: TLÜ Kirjastus, lk 84-92.

Vi itso, Tiit-Rein 1979. Проблемы количества в эстонском языке. - Советское финноугроведение, kd 1, lk 1-17. 


\section{How Much Grammar Do We Need?}

Keywords: standard language, language and power, grammar and literacy education

According to Bourdieu, the knowledge of standard language is a linguistic capital that could be used to gain other types of capital. This means that there is a constant need for learning the standard language. The paper argues that the language that is used to describe the standard is written in the jargon of linguistics presupposing the knowledge of the structure of language and grammatical terminology. Using the linguistic jargon helps to maintain the linguists monopoly over the formulation of legitimate language. However, the norms of the standard language could also be formulated in a considerably simpler language. The paper analyses several subfields of orthography and concludes that most of the rules can be formulated using intuitively understandable notions and common vocabulary. Such descriptions would drastically reduce the need for grammatical instruction in literacy teaching.

Martin Ehala (b. 1963), PhD, University of Tartu, professor of literacy education, senior researcher, ehalam@ut.ee 